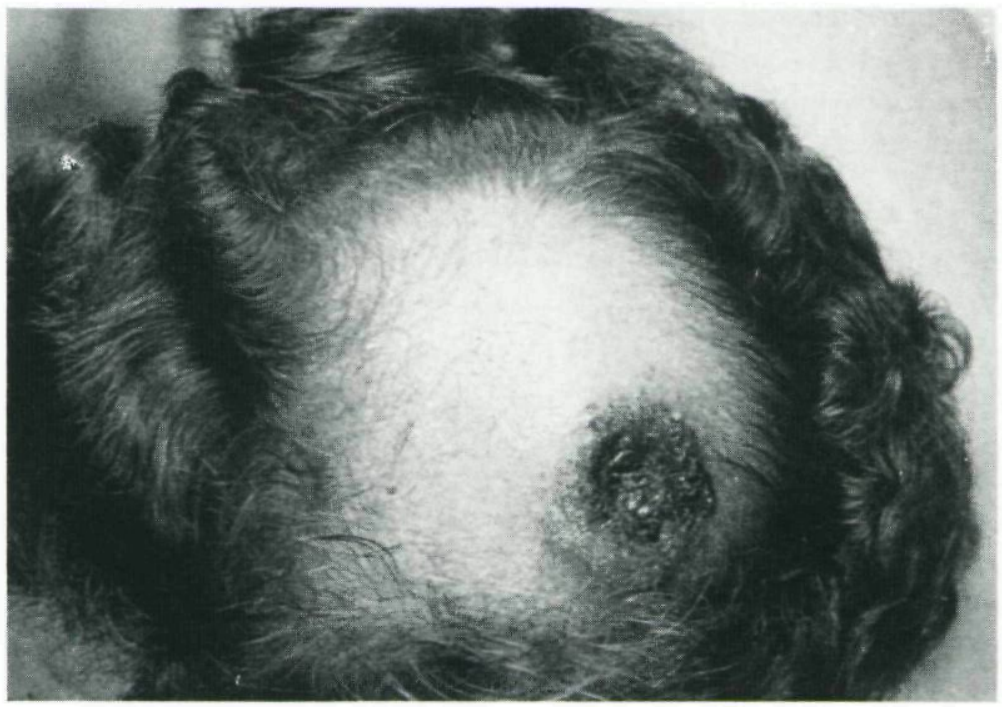

FIGURE I. Cutaneous T-cell lymphoma after successful treatment of follicular B-cell lymphoma.

1983. IgH gene analysis showed a monoclonal B-cell population in the lymph-node biopsy of 1983 but not in the 1988 skin biopsy.

Comment. The disorder was diagnosed as a cutaneous $\mathrm{T}$-cell lymphoma and developed in a patient who was successfully treated for a follicular B-cell lymphoma. The occurrence of two malignancies in one patient can be explained by a high susceptibility for lymphoma, or the development of a second lymphoma may have been due to previous treatment with cytostatic drugs.

\title{
REFERENCES
}

I Van Dongen JJM, Adriaansen HJ, Hooijkaas H. Immunophenotyping of leukaemias and non-Hodgkin's lymphomas. Immunological markers and their CD codes. Neth f Med I988; 33: 298-314.

2 Van Dongen JJM, Adriaansen HJ, Hooijkaas H. Immunoglobuline genen en T-cel-receptor-genen en de expressie van immunologische markers. II. Immunologische diagnostiek van maligne lymfatische ziekten. Ned Tijdschr Geneeskd 1988; 132: 862-8.

\section{Diffuse cutaneous mastocytosis}

\section{A.H.van der Willigen and A.P.Oranje}

\section{Department of Dermatology and Venereology, University Hospital, Rotterdam}

History. A few hours after birth the patient was referred to the Sophia Children's Hospital in view of extensive skin lesions present since birth. Pregnancy and delivery had been uneventful. The first child in this family was healthy. There was no family history of hereditary or congenital diseases. 
Examination. There were multiple plaques scattered over the entire body surface, and some of these had linear vesicles. Almost the entire skin was erythematous, the redness varying in intensity. Several ecchymoses were visible in the scalp. The trunk was covered with a parchment-like membrane. Darier's sign was positive.

Histology. Biopsy I (affected skin on leg). There was separation of the epidermis, with the formation of bullae at the dermal-epidermal junction. The dermis contained a band-like infiltrate of cells with ill-defined contours and slight polymorphism and often with oval-shaped nuclei. Biopsy 2 (unaffected skin on leg). The same cellular infiltrate was found in the dermis.

In both specimens, toluidine blue staining revealed many mast cells.

Additional investigations. Direct smear (Tzanck test) of vesicle contents revealed numerous mast cells. The total blood and differential counts as well as the bleeding and clotting times were all normal. Liver and renal function tests were within normal limits. Prostaglandin D2 metabolites in 24 -h urine were normal. Histamine-breakdown products in a 24 -h urine specimen showed that imidazoles were slightly increased.

Treatment and course. Treatment was started with oxatomide and sodium cromoglycate $\left(\right.$ Nalcrom $\left.^{*}\right)$. Bullae and urticarial lesions developed diffusely over the body surface with varying severity. At I'5 years the bullae stopped appearing and sodium cromoglycate therapy was stopped.

Comment. Mastocytosis can develop at any age, and congenital forms have been previously described. ${ }^{1-4}$ The lesions appear before age 2 in $75 \%$ of cases. There are only a few reports on diffuse cutaneous mastocytosis with extensive bullae formation in neonates. The skin features are variable and there may be leather-like thickening or smoothness, but it may also show small papules. The colour may range from a diffuse yellow-orange to red. Multiple mastocytomas and extensive bullae may form. In rare cases the skin lesions may be totally absent.

The prognosis of mastocytosis depends on the age of onset. With the onset prior to the age of 5 the prognosis is good and the bullae usually cease by the age of $\mathrm{I}-3$, and $90 \%$ of patients no longer have any symptoms by the time they reach puberty. The involvement of internal organs in young children is rare.

\section{REFERENCES}

I Harrison PV, Cook LJ, Lake HJ et al. Diffuse cutaneous mastocytosis: a report of neonatal onset. Acta Derm Venereol (Stockh) 1979; 59: 54I-3.

2 Willemze R, Ruiter DJ, Scheffer E et al. Diffuse cutaneous mastocytosis with multiple cutaneous mastocytomas. Br $\mathcal{F}$ Dermatol 1980; 102: 601-7.

3 Kendall ME, Fields JP, King LE. Cutaneous mastocytosis without clinically obvious skin lesions. $f \mathrm{Am} \mathrm{Acad}$ Dermatol 1984; 10: 903-5.

4 Golitz LE, Weston WL, Lane AT. Bullous mastocytosis: diffuse cutaneous mastocytosis with extensive blisters mimicking scalded skin syndrome or erythema multiforme. Pediatr Dermatol 1984; 1: 288-94. 
This document is a scanned copy of a printed document. No warranty is given about the accuracy of the copy. Users should refer to the original published version of the material. 